\title{
Variability and Grouping of Northwestern Spanish Chestnut Cultivars. II. Isoenzyme Traits
}

\author{
S. Pereira-Lorenzo \\ Departamento de Ingeniería Agroforestal y Producción Vegetal, Universidad de Santiago de Compostela, \\ Campus de Lugo, 27002 Lugo, Spain \\ J. Fernández-López \\ Centro de Investigaciones Forestales de Lourizán, Apartado 127, 36080 Pontevedra, Spain \\ J. Moreno-González \\ Centro de Investigaciones Agrarias de Mabegondo, Apartado 10, 15080 La Coruña, Spain
}

Additional index words. Castanea sativa, genetic variation, numerical taxonomy, markers

\begin{abstract}
Two-hundred and ninety-five trees sampled from seventy-five local chestnut (Castanea sativa Mill.) cultivars in northwestern Spain, which had been previously studied morphologically, were further analyzed for five isoenzyme systems, encoded by seven loci. Objectives of this study were to 1) describe the intracultivar and intercultivar variability by isoenzyme analysis and to compare it with the morphological variation and 2) establish a classification of the cultivars and to discuss its relation to the morphological classification. Variability within and among cultivars was detected, confirming the previous morphological results. The level of the observed heterozygosity in this Spanish population was higher than expected and also higher than that found in other European populations. Because of the great diversity discovered, this material seems to be worthy for introducing and maintaining in a germplasm bank. Nineteen main clusters were identified for the twenty-three most widely distributed cultivars. On the average, $61 \%$ of the trees belonging to a specific cultivar was included in the same cluster. The remaining $39 \%$ was scattered in other clusters, which indicates intracultivar variability. Therefore there is opportunity for selection within cultivars. Two clusters included three important cultivars each. This suggests possible synonymies. No correlation between morphological traits and the isoenzymic alleles was detected. The isoenzyme technique identified a higher number of cultivars increasing the information obtained with morphological traits. Correlations between the frequency of some of the alleles and the altitude and other environmental variables suggest that selection of the best adapted genotypes has occurred.
\end{abstract}

Morphological characterization is the only official method accepted for registration and protection of new cultivars. However, cultivars can be distinguished not only by their morphological traits, but also by their biochemical, genetic and physiological characteristics (Bailey, 1983). The polymorphic isoenzymes are useful for genotype identification because of their codominant expression and independence from environmental effects. Isoenzymes also may be useful when deciding the diversity to be preserved in germplasm banks (Soller and Beckmann, 1983), particularly in tree crops where physical space is a limiting factor.

Grafted cultivars of chestnuts (Castanea sativa) from the Northwestern part of Spain have been inventoried (Fernández and Pereira, 1993) and subsequently characterized using morphological traits (Pereira, 1994; Pereira et al., 1995). Many of the morphological characteristics were directly studied in field conditions. A large variability within and among cultivars was observed. However, it is not known whether this morphological variability was due to genetic, environmental or genotype $\times$ environmental interaction, since cultivars were not planted in common locations. To solve this problem an isoenzymic study was conducted on most of the trees which had been previously analyzed for morphological traits.

Isoenzymic techniques have been used to characterize and identify cultivars of Japanese (C. crenata), Chinese (C. mollis-

Received for publication 8 June 1995. Accepted for publication 18 Sept. 1995. Part of a thesis submitted by S. Pereira-Lorenzo as requirement for the $\mathrm{PhD}$ degree, Universidad Politécnica de Madrid. This research was funded in part by the INIA and the Dirección Xeral de Montes (Xunta de Galicia). The cost of publishing this paper was defrayed in part by the payment of page charges. Under postal regulations, this paper therefore must be hereby marked advertisement solely to indicate this fact. sima), and European (C. sativa) chestnut species (Sawano et al., 1984; Huang et al., 1994), Italian (C. sativa) (Fineschi et al., 1994; Giannini et al. 1993) and Swiss (Muller-Starck et al., 1993) species, and C. crenata, C. sativa, and interspecific hybrids (Fernandez et al., 1994).

The objectives of this study were to 1) describe both the intraand intercultivar variability through isoenzyme analysis and to compare it with the morphological variation and 2) establish a classification of the cultivars and to discuss its relation to the morphological classification.

\section{Material and Methods}

Plant material. Two-hundred and ninety-five trees were studied. Among them, 286 corresponded to 75 cultivars named by local farmers and the remaining 9 trees were of unknown origin (Table 1). These trees had previously been classified using morphological traits (Pereira et al., 1995). Most of the chestnut growing areas in Galicia, Northwestern Spain, were sampled. One tree per each present cultivar at each sampled location was collected and grafted on to the hybrid rootstock HS in a collection. For some scarce cultivars, only one tree was found (Fernández and Pereira, 1993).

Electrophoresis and isoenzyme staining. The following five isoenzyme systems were studied: isocitrate dehydrogenase (IDH; EC 1.1.1.42), phosphoglucoisomerase (PGI; EC 5.3.1.9), phosphoglucomutase (PGM;EC2.7.5.1.), malate dehydrogenase (MDH; EC 1.1.1.37), and shikimate dehydrogenase (SKDH;EC 1.1.1.25). Previous work has solved seven loci for these isoenzymes (Fernández, 1992; Fernández et al., 1993). The separation was carried out by electrophoresis in starch using leaf extracts. The extraction buffer was described by Aletà et al. (1990). The gel and 
electrode buffers were defined by Shields et al. (1983) for MDH, PGI, and PGM and by Kephart (1990) for SKDH and IDH. The staining procedures were from Vallejos (1983).

Genetic parameters. To quantify genetic variability, the following parameters were computed for all of the trees sampled: a) average number of alleles per locus (A), b) average number of alleles per polymorphic locus (AP), c) percentage of polymorphic loci (PLP), d) average allele frequency, e) observed heterozygosity $(\mathrm{H}), \mathrm{f})$ within-cultivar expected heterozygosity (Hs), g) expected heterozygosity in the whole panmictic population $(\mathrm{Ht}), \mathrm{h})$ fixation index (deviation between the expected and observed heterozygosity relative to the expected within cultivars, Fis), and i) fixation index in the whole population (Fit) (Gottlieb, 1981; Nei, 1972, 1977).
Environmental variables. The following environmental indexes were recorded at each sample location: the effective thermal index of Winkler and Amerine (ETI) (Hidalgo, 1980), the accumulated rainfall from April to October (RAO) and from July and October (RJO), and the altitude (ALT).

Statistical analyses. Similarity relationships among the samples were studied using multivariate analysis techniques. For each tree the frequency of each isozymic allele was assigned to a variable, with values $1,0.5$ and 0 for homozygosity, heterozygosity, and absence of the allele, respectively. Principal components (PCs) were estimated on the variance-covariance matrix of the allele frequencies (Goodman, 1973; Llauradó et al., 1993) using the PROC PRINCOMP of SAS. Dispersion diagrams of the trees were elaborated using the first PC. A cluster analysis (UPGMA) was

Table 1. Spanish chestnut cultivars and number of trees per cultivar.

\begin{tabular}{|c|c|c|c|c|c|}
\hline No. & Cultivar & No. trees & No. & Cultivar & No. trees \\
\hline$\overline{1}$ & Abadá & 3 & 45 & Palmeiros & $--^{z}$ \\
\hline 2 & Abarcá & 1 & 46 & Paradesa & 1 \\
\hline 3 & Amadengue & --- & 47 & De Parede & 12 \\
\hline 4 & Amarelante & 21 & 48 & Patacuda & 1 \\
\hline 5 & Anaxa & 1 & 49 & Pelada & 4 \\
\hline 6 & Das Anchas & 1 & 50 & Peluda & 1 \\
\hline 7 & Areal & 2 & 51 & Picona & 2 \\
\hline 8 & Berciana & --- & 52 & Porteliña & 1 \\
\hline 9 & Bermella & 4 & 53 & Portuguesa & 2 \\
\hline 10 & Blanca & 13 & 54 & Pozoredondo & 2 \\
\hline 11 & Bolesas & --- & 55 & Praga d'Afora & 4 \\
\hline 12 & Bravo de Leirado & 3 & 56 & Praga do Bolo & 3 \\
\hline 13 & Burgaceira & 1 & 57 & De Presa & 10 \\
\hline 14 & Cabezuda & 2 & 58 & De Puga & 1 \\
\hline 15 & Calva & 4 & 59 & Puga do Receiro & 1 \\
\hline 16 & Campilla & 1 & 60 & Raigona & 13 \\
\hline 17 & Carrelao & 1 & 61 & Rañuda & 1 \\
\hline 18 & Castelás & 1 & 62 & Rapada & 15 \\
\hline 19 & Caurelal & --- & 63 & Redondo & 1 \\
\hline 20 & De Cedo & 2 & 64 & Riá & 2 \\
\hline 21 & Cerreda & 1 & 65 & Ribeirá & 1 \\
\hline 22 & Courelá & 7 & 66 & Rosendas & 1 \\
\hline 23 & Culona & 3 & 67 & Rozada & 1 \\
\hline 24 & Curuxa & 1 & 68 & Salnesa & 2 \\
\hline 25 & Desgrañadiza & 2 & 69 & Sergude & 1 \\
\hline 26 & Famosa & 13 & 70 & Serodia & 5 \\
\hline 27 & Galega & --- & 71 & Soutogrande & 1 \\
\hline 28 & Garrida & 7 & 72 & Tarabelao & 1 \\
\hline 29 & Garriga & --- & 73 & Temperá & 6 \\
\hline 30 & Horrón & 1 & 74 & Torbeana & 1 \\
\hline 31 & Inxerta & 9 & 75 & Toubesa & 1 \\
\hline 32 & Da Lebre & 1 & 76 & Veiguiña & 1 \\
\hline 33 & De Lemos & 3 & 77 & Ventura & 7 \\
\hline 34 & Longal & 7 & 78 & Verde & 17 \\
\hline 35 & Loura & 10 & 79 & Vileta & 2 \\
\hline 36 & Luguesa & 7 & 80 & Villarenga & 1 \\
\hline 37 & Maceirá & 1 & 81 & Xabrega & 7 \\
\hline 38 & De San Miguel & 1 & 82 & Xilimendra & 1 \\
\hline 39 & Monfortina & 1 & & & \\
\hline 40 & Negral,Queiroguesa & 10 & & Unknown origin & \\
\hline 41 & Ouriza & 2 & & Bolo & U1 \\
\hline 42 & Outeira & 1 & & Cerdedo & $\mathrm{U} 2, \mathrm{U} 3, \mathrm{U} 4$ \\
\hline 43 & País & 2 & & Ponteareas & U5, U6, U7, \\
\hline 44 & Pallarego & 1 & & & U12, U14 \\
\hline
\end{tabular}

${ }^{\mathrm{z} N o t}$ included in the analysis. 
performed based on modified Rogers' genetic distance (Wright, 1978) computed between each pair of trees using the PROC CLUSTER of SAS.

Pearson correlation coefficients were estimated for the environmental variables, the three first principal components and the allele frequencies of the isoenzymic loci. The correlation coefficients between the frequency of segregating isoenzymic alleles and some morphological traits studied previously (Pereira et al., 1995) were also calculated for the same set of trees.

\section{Results and Discussion}

Genetic diversity. The seven isoenzymic loci and the frequency of their alleles are presented in Table 2. Locus $M d h-1$ was monomorphic in all trees. The alleles $P g i-2 b, M d h-2 b, M d h-3 a, I d h-2 b$, and $S k d h-b$ were found at relatively low frequencies $(<0.25)$. The average number of alleles per locus examined (2.14) was higher than those found in natural populations in France (1.86, Bonnefoi, 1984), and Italy (1.93; Pigliucci et al., 1990), but lower than in the Turkish population (2.69; Villani et al., 1991). The average number of alleles per polymorphic locus (AP) is similar among the Galician cultivars (2.33) and the Italian and French populations, while the Turkish population reaches the highest level (2.80). The expected heterozygosity varied between 0.264 for the locus Idh-2 and 0.587 for the locus $S k d h-1$, with an average value of 0.360 (Table 2). The loci $M d h-2, M d h-3, I d h-2, S k d h-1$, and Pgm-2 showed an excess of heterozygotes, while the Pgi-2 showed lack of heterozygotes. The fixation index (Fit) over all polymorphic loci in the whole Galician population was -0.284 indicating an excess of heterozygotes, in contrast to the general situation in other European populations, which have positive values (Bonnefoi, 1984; Pigliucci et al., 1990; Villani et al., 1991). Inbreeding and excess of homozygotes are inherent to the mating of individuals related by geographical proximity and limitation in gene flow. The excess of heterozygotes in the Galician population might be explained because the cultivated trees are clones that farmers may have chosen for their hybrid vigor and, therefore, with an excess of heterozygotes. Crossing between unrelated trees and subsequent asexual propagation through grafting might also help to create and maintain this situation.

Intracultivar variability. The genetic variability among trees within cultivars was analyzed for those 42 cultivars that had more than 1 tree sampled (Table 3). The number of alleles per locus varied from 1.1 in cultivars of limited distribution to 2.1 in 'Blanca', 'Famosa', and 'Loura', cultivars of greater economical importance. The proportion of polymorphic loci (PLP) varied from $14.3 \%$ in 'Arial' up to $85.7 \%$ found in 17 different cultivars. Important cultivars such as 'Parede', 'Presa', 'Serodia', and 'Ventura' showed $57.1 \%$ of polymorphic loci, while other important cultivars such as 'Amarelante', 'Blanca', 'Famosa', 'Loura', 'Negral', 'Rapada', and 'Verde' had a $85.7 \%$ PLP. The values of expected heterozygosity (Hs) varied from 0.071 in 'Arial' up to 0.421 in the trees studied from the location Cerdedo of unknown varietal denomination. Important cultivars like 'Luguesa', 'Parede' and 'Presa' showed a low Hs: $0.118,0.186$, and 0.179 , respectively. All cultivars, except one, had negative fixation index (Fis) values. This reveals that the frequency of observed heterozygotes is much higher than expected in a panmictic population. The case is more striking for cultivars with low variability (AL 1.4 and PLP 42.9) which have Fis values of -1.00 . This indicates that polymorphic loci are mainly heterozygous in cultivars of low variability. The average of the fixation index for all the cultivars (Fis) was 0.500 and for the whole population (Fit) -0.284 . The difference between these values relative to 1 -Fis is the relative genetic differentiation among the cultivars (Nei, 1977).

Most of the cultivars showed intracultivar variability and these results are consistent with the study of the morphological traits (Pereira et al., 1995). If trees were vegetatively propagated, the cause of the genetic variation found within cultivars may be due to 1) mistakes of farmers when gathering the scion for grafting, since grafting is made at the time when there is no fruit for checking all the distinguishing characteristics of the cultivar; 2) misnaming that would produce synonymies; 3 ) occasional sexual reproduction of the cultivar due to a belief of some farmers that the central chestnut of the burr produces a similar offspring to its progenitors; and 4) mutation, although no bibliographical refer-

Table 2. Estimates of genetic diversity parameters in 295 spanish chestnut trees corresponding to 75 putative cultivars using 7 isoenzyme loci.

\begin{tabular}{|c|c|c|c|c|c|}
\hline Alleles & Loci & $\begin{array}{c}\text { Allele } \\
\text { frequency }\end{array}$ & $\mathrm{H}^{\mathrm{z}}$ & $\mathrm{Ht}^{\mathrm{y}}$ & $\mathrm{Fit}^{\mathrm{x}}$ \\
\hline$\overline{M d h-1}$ & $M d h 1$ & 1.000 & 0.000 & 0.000 & --- \\
\hline$M d h-2 a$ & $M d h 2$ & 0.807 & 0.380 & 0.312 & -0.218 \\
\hline$M d h-2 b$ & & 0.193 & & & \\
\hline$M d h-3 a$ & $M d h 3$ & 0.212 & 0.424 & 0.335 & -0.269 \\
\hline$M d h-3 b$ & & 0.788 & & & \\
\hline$I d h-2 a$ & $I d h 2$ & 0.844 & 0.312 & 0.264 & -0.185 \\
\hline$I d h-2 b$ & & 0.156 & & & \\
\hline Skdh-a & Skdhl & 0.434 & 0.671 & 0.587 & -0.146 \\
\hline$S k d h-b$ & & 0.102 & & & \\
\hline$S k d h-c$ & & 0.464 & & & \\
\hline$P g i-2 a$ & Pgi2 & 0.531 & 0.485 & 0.526 & 0.077 \\
\hline$P g i-2 b$ & & 0.031 & & & \\
\hline$P g i-2 c$ & & 0.439 & & & \\
\hline Pgm-2a & Pgm2 & 0.519 & 0.963 & 0.500 & -0.928 \\
\hline Pgm-2b & & 0.481 & & & \\
\hline Average & & & 0.462 & 0.360 & -0.284 \\
\hline
\end{tabular}


ences for this mechanism in chestnut have been found.

Intercultivar variability. The first three principal components (PC) can explain $73 \%$ of the total variance (Table 4). The first principal component accumulates $33 \%$ of the total variation and separates the clones on the basis of the alleles Pgi-2a and Pgi-2c. The discrimination of the second PC which explains $24 \%$ additional variance, is mainly due to the alleles $S k d h-a$ and $S k d h-c$. In the third principal component the discrimination is produced mainly by the alleles $M d h-2 b, M d h-3 a, I d h-2 a, S k d h-b$, and Pgi-2a with positive values, and by the alleles $P g i-2 c, I d h-2 b$, and $S k d h$ $a$ with negatives. The alleles $M d h-2 a$ and $M d h-3 b$ were found in all the trees, having a higher weight when they are homozygous.

A cluster analysis performed with the modified Rogers genetic distance resulted in 59 clusters (F1 to F59) corresponding to the 59 different genotypes or combinations of alleles found in the isozymic analysis (Fig. 1). The 23 most widely distributed cultivars represented by at least four trees, which included 214 trees out of 286 studied, were further inspected by looking at the results of the cluster analysis. Nineteen main clusters could be identified for these twenty-three cultivars (Table 5). Each cluster was dominated by only one cultivar, except clusters F13 and F46, which were both dominated by three cultivars. On average, $61 \%$ of the trees of the dominating cultivars were included in their corresponding cluster, and the remaining trees were scattered in other clusters. A moderate proportion of trees from the same cultivar were also grouped in the same cluster when analyzing the morphological traits (Pereira

Table 3. Parameters ${ }^{\mathrm{z}}$ of genetic diversity in the chestnut cultivars with more than one tree.

\begin{tabular}{|c|c|c|c|c|c|c|c|}
\hline Cultivar & Sample & NA & $\mathrm{A}$ & PLP & $\mathrm{H}$ & Hs & Fis \\
\hline Abadá & 3 & 11 & 1.6 & 57.1 & 0.190 & 0.206 & 0.078 \\
\hline Amarelante & 21 & 14 & 2.0 & 85.7 & 0.544 & 0.376 & -0.447 \\
\hline Arial & 2 & 8 & 1.1 & 14.3 & 0.143 & 0.071 & -1.000 \\
\hline Bermella & 4 & 13 & 1.9 & 85.7 & 0.517 & 0.357 & -0.448 \\
\hline Blanca & 13 & 15 & 2.1 & 85.7 & 0.505 & 0.369 & -0.369 \\
\hline Bravoleirado & 3 & 11 & 1.6 & 57.1 & 0.429 & 0.246 & -0.744 \\
\hline Cabezuda & 2 & 10 & 1.4 & 42.9 & 0.429 & 0.214 & -1.000 \\
\hline Calva & 4 & 13 & 1.9 & 85.7 & 0.607 & 0.371 & -0.636 \\
\hline Cedo & 2 & 10 & 1.4 & 42.9 & 0.429 & 0.214 & -1.000 \\
\hline Cerdedo & 3 & 14 & 2.0 & 85.7 & 0.619 & 0.421 & -0.470 \\
\hline Courelá & 7 & 13 & 1.9 & 71.4 & 0.510 & 0.343 & -0.487 \\
\hline Culona & 3 & 12 & 1.7 & 71.4 & 0.333 & 0.310 & -0.074 \\
\hline Desgranadiza & 2 & 13 & 1.9 & 85.7 & 0.571 & 0.357 & -0.599 \\
\hline Famosa & 13 & 15 & 2.1 & 85.7 & 0.462 & 0.297 & -0.556 \\
\hline Garrida & 7 & 13 & 1.9 & 71.4 & 0.347 & 0.243 & -0.428 \\
\hline Inxerta & 9 & 12 & 1.7 & 71.4 & 0.413 & 0.273 & -0.513 \\
\hline Lemés & 3 & 12 & 1.7 & 71.4 & 0.476 & 0.317 & -0.502 \\
\hline Longal & 7 & 12 & 1.7 & 71.4 & 0.469 & 0.252 & -0.861 \\
\hline Loura & 10 & 15 & 2.1 & 85.7 & 0.557 & 0.354 & -0.573 \\
\hline Luguesa & 7 & 11 & 1.6 & 42.9 & 0.184 & 0.118 & -0.559 \\
\hline Negral & 10 & 14 & 2.0 & 85.7 & 0.543 & 0.353 & -0.538 \\
\hline Ouriza & 2 & 13 & 1.9 & 85.7 & 0.571 & 0.357 & -0.599 \\
\hline País & 2 & 10 & 1.4 & 42.9 & 0.429 & 0.214 & -1.000 \\
\hline Parede & 12 & 12 & 1.7 & 57.1 & 0.310 & 0.186 & -0.667 \\
\hline Pelada & 4 & 11 & 1.6 & 57.1 & 0.429 & 0.241 & -0.780 \\
\hline Picona & 2 & 10 & 1.4 & 42.9 & 0.429 & 0.214 & -1.000 \\
\hline Ponteareas & 5 & 12 & 1.7 & 42.9 & 0.371 & 0.243 & -0.527 \\
\hline Portuguesa & 2 & 9 & 1.3 & 28.6 & 0.286 & 0.143 & -1.000 \\
\hline Pozoredondo & 2 & 13 & 1.9 & 85.7 & 0.500 & 0.339 & -0.475 \\
\hline Praga d'Afora & 4 & 13 & 1.9 & 85.7 & 0.500 & 0.304 & -0.645 \\
\hline Praga do Bolo & 3 & 13 & 1.9 & 85.7 & 0.619 & 0.373 & -0.660 \\
\hline Presa & 10 & 11 & 1.6 & 57.1 & 0.300 & 0.179 & -0.676 \\
\hline Raigona & 13 & 12 & 1.7 & 71.4 & 0.604 & 0.351 & -0.721 \\
\hline Rapada & 15 & 14 & 2.0 & 85.7 & 0.448 & 0.343 & -0.306 \\
\hline Riá & 2 & 11 & 1.6 & 57.1 & 0.571 & 0.286 & -0.997 \\
\hline Salnesa & 2 & 12 & 1.7 & 71.4 & 0.500 & 0.304 & -0.645 \\
\hline Serodia & 5 & 12 & 1.7 & 57.1 & 0.400 & 0.260 & -0.539 \\
\hline Temporá & 6 & 14 & 2.0 & 85.7 & 0.476 & 0.341 & -0.396 \\
\hline Ventura & 7 & 11 & 1.6 & 57.1 & 0.449 & 0.233 & -0.927 \\
\hline Verde & 17 & 14 & 2.0 & 85.7 & 0.513 & 0.322 & -0.593 \\
\hline Vileta & 2 & 11 & 1.6 & 57.1 & 0.571 & 0.286 & -0.997 \\
\hline Xábrega & 7 & 13 & 1.9 & 85.7 & 0.571 & 0.356 & -0.604 \\
\hline Average & 259 & & 1.74 & 67.7 & 0.455 & 0.284 & -0.631 \\
\hline Average over all cultivars & 295 & 15 & 2.14 & 85.7 & 0.462 & 0.308 & -0.500 \\
\hline
\end{tabular}

${ }^{\mathrm{z}} \mathrm{NA}=$ total number of alleles, $\mathrm{A}=$ average number of alleles per locus, $\mathrm{PLP}=$ percentage of polymorphic loci, $\mathrm{H}=$ observed heterozygosity, $\mathrm{Hs}=$ expected heterozygosity, Fis = fixation index within cultivars. 
Table 4. Principal components on the variance-covariance matrix of the allelic frequencies per tree.

\begin{tabular}{lccc}
\hline \hline Allele & PRIN1 & PRIN2 & PRIN3 \\
\hline$M d h-2 a$ & 0.121 & -0.285 & -0.335 \\
$M d h-2 b$ & -0.121 & 0.285 & 0.335 \\
$M d h-3 a$ & -0.229 & 0.031 & 0.383 \\
$M d h-3 b$ & 0.229 & -0.031 & -0.383 \\
$I d h-2 a$ & -0.202 & -0.061 & 0.301 \\
$I d h-2 b$ & 0.202 & 0.061 & -0.301 \\
Skdh- $a$ & -0.055 & 0.704 & -0.256 \\
Skdh- $b$ & -0.004 & -0.179 & 0.232 \\
Skdh-c & 0.058 & -0.525 & 0.025 \\
$P g i-2 a$ & 0.646 & 0.129 & 0.278 \\
$P g i-2 b$ & -0.049 & -0.064 & 0.019 \\
$P g i-2 c$ & -0.597 & -0.065 & -0.297 \\
$P g m-2 a$ & -0.039 & -0.019 & -0.085 \\
Pgm-2b & 0.039 & 0.019 & 0.085 \\
Eigen value & 0.30 & 0.22 & 0.14 \\
Accumulated variation & $33 \%$ & $57 \%$ & $73 \%$ \\
Pearson correlation & & & \\
$\quad$ ALT & NS & -0.19 & -0.14 \\
ETI & NS & 0.19 & NS \\
RAO & 0.17 & -0.30 & NS \\
RJO & 0.18 & -0.21 & NS \\
\hline NSNonsignificant at $P>0.05$ & & &
\end{tabular}

et al., 1995). These results can be interpreted as follows: a) significant variability was found among clusters, and therefore also among cultivars; $b$ ) some of the trees collected under the same cultivar name ( $39 \%$ on average) were represented in clusters other than the one dominated by that cultivar, therefore there is intracultivar variability, at least variability within a cultivar name; c) since two groups (i.e., F13 and F46) were dominated by more than one cultivar, either synonymy exists but is not very important among the main cultivars or the studied loci were insufficient to discriminate all the cultivars. Implications of these results are that selection should be based on both cultivars and trees within cultivars.

The discrimination power of isoenzyme seems to be higher than that of morphological traits, since 19 main clusters were associated to the most important cultivars when using the isoenzyme analysis while eight groups only were identified when using morphological traits (Pereira et al., 1995). The two classifications do not closely correspond. Some cultivars classified by morphological traits in the same morphological group VIII (Table 6) are however separated in the isoenzyme dendogram (Fig. 1); e.g., 'Parede' and 'Amarelante' in group VIII are discriminated by isoenzyme at a Rogers Distance above 0.33. This suggests that there has been a genetic differentiation that has not been reflected in morphological traits that indicates these two cultivars are not synonymous. Thus, morphological traits and isoenzyme genotypes should be considered supplementary for the distinctiveness of the cultivars.

Unknown cultivars assigned to different groups (Pereira et al., 1995) couldn't be identified with the studied cultivars (Fig. 1), since the allelic composition is different to them (Fig. 1).

Correlation. The correlations between the PCs of the allelic frequencies per tree and the environmental variables were low (Table 4). The first principal component was significantly correlated to the rainfall accumulated from April to October (RAO) and from July to October (RJO). The second PC was correlated to the altitude (ALT), the environmental thermal integral (ETI), RAO, and RJO. Also, the correlation coefficients between the frequency of alleles and the environmental parameters were low (Table 7). Pres-

Table 5. Main clusters dominated by trees of the most widely distributed cultivars. In brackets are the number of trees within the same cluster. Twenty-three of the most important cultivars were found in nineteen main clusters.

\begin{tabular}{llllr}
\hline \hline No. & Cultivar & $\begin{array}{c}\text { Main } \\
\text { cluster }\end{array}$ & \multicolumn{1}{c}{$\begin{array}{c}\text { Trees in other } \\
\text { clusters }\end{array}$} & $\begin{array}{c}\text { Trees in } \\
\text { main cluster (\%) }\end{array}$ \\
\hline 4 & Amarelante & F43(9) & F7(3),F8(1),F10(1),F13(1),F21(1),F27(1),F34(1),F44(2),F50(1) & 42.9 \\
9 & Bermella & F23(2) & F28(1),F46(1) & 50.0 \\
13 & Blanca & F24(6) & F11(1),F19(1),F23(1),F25(1),F35(1),F39(1),F51(1) & 46.2 \\
15 & Calva & F10(2) & F6(1),F15(1) & 50.0 \\
22 & Courelá & F46(4) & F32(3) & 57.1 \\
23 & Famosa & F26(8) & F32(1),F41(2),F54(1),F55(1) & 61.5 \\
28 & Garrida & F20(5) & F3(1),F6(1) & 71.4 \\
31 & Inxerta & F41(6) & F12(1),F37(1),F40(1) & 66.7 \\
34 & Longal & F27(6) & F23(1) & 85.7 \\
35 & Loura & F42(7) & F3(1),F13(1),F45(1) & 70.0 \\
36 & Luguesa & F25(6) & F37(1) & 85.7 \\
40 & Negral & F46(5) & F24(2),F28(1),F39(1),F44(1) & 50.0 \\
47 & Parede & F16(9) & F13(1),F29(1),F30(1) & 75.0 \\
49 & Pelada & F7(3) & F3(1) & 75.0 \\
55 & Praga d'Afora & F13(3) & F44(1) & 75.0 \\
57 & De Presa & F34(8) & F13(1),F16(1) & 80.0 \\
60 & Raigona & F44(8) & F17(1),F40(1),F46(3) & 61.5 \\
62 & Rapada & F13(7) & F6(1),F13(7),F14(1),F27(1),F32(1),F41(1),F43(1),F46(1),F57(1) & 46.7 \\
70 & Serodia & F13(2) & F15(1),F27(1),F30(1) & 40.0 \\
73 & Temperá & F3(3) & F26(1),F46(1),F52(1) & 50.0 \\
77 & Ventura & F12(6) & F8(1) & 85.7 \\
78 & Verde & F32(6) & F13(2),F16(1),F21(2),F22(1),F27(1),F30(1),F33(1),F44(2) & 35.3 \\
81 & Xabrega & F46(3) & F13(1),F18(1),F48(2) & 42.9 \\
Average & & & 61.1 \\
\hline
\end{tabular}




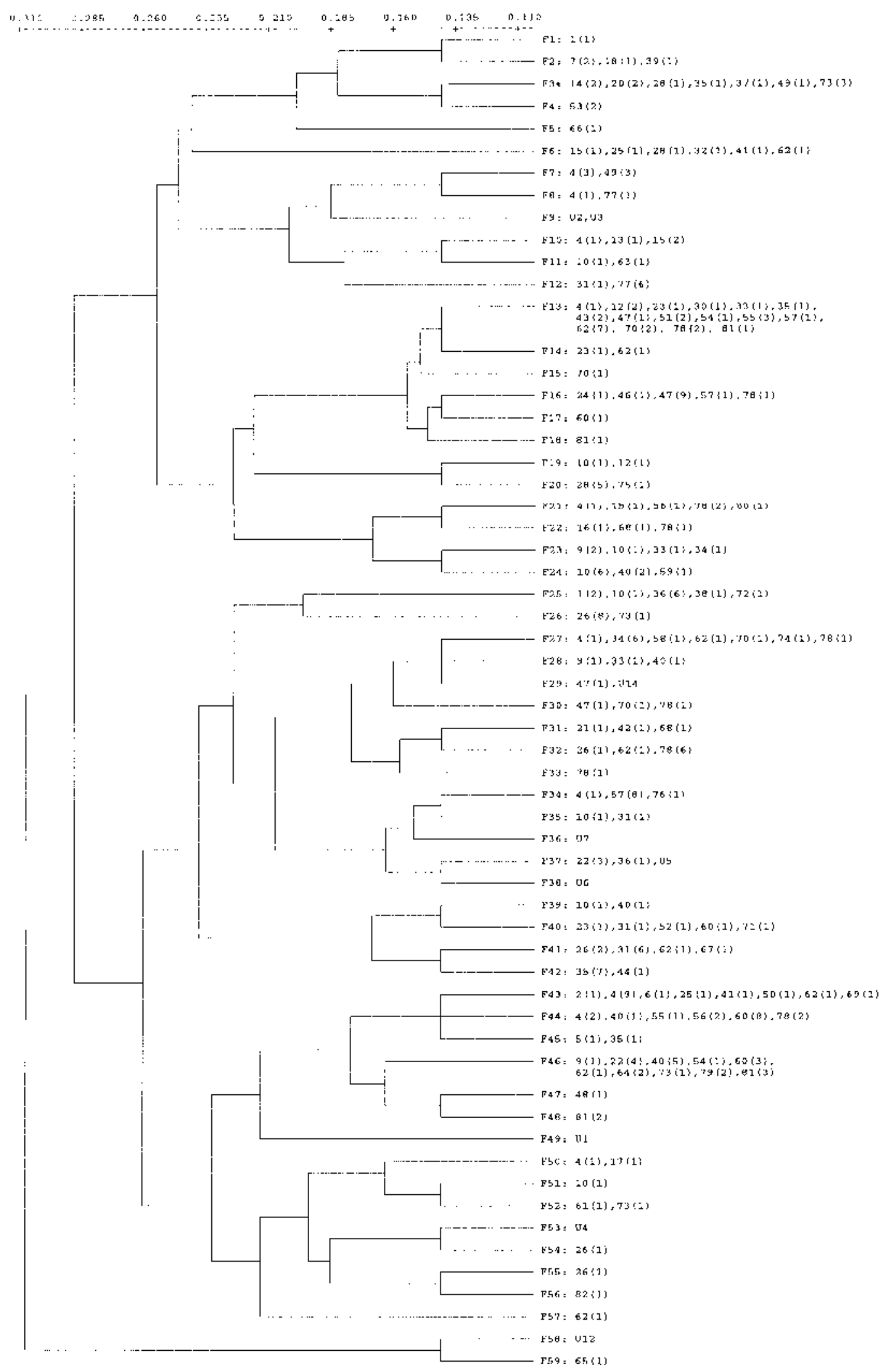

Fig. 1. Average linkage dendrogram of 295 trees corresponding to 75 cultivars of chestnut from northen Spain based on the allozyme data and modified Rogers' distance. In brackets is the number of trees belonging to the same cultivar. The trees whose name is unknown are designated with the letter $\mathrm{U}$.

ence of alleles $M d h-2 a$ and $S d k h-c$ are slightly associated to higher altitude and rainfall and lower ETI. This means that these alleles may be found in cultivars sampled in wet areas, whereas the other alleles of the same loci may be found in cultivars from drier areas.

The lack of correlation between the frequency of the isoenzymic alleles and the morphological traits used to classify the 
Table 6. Cultivars included in the eight groups of the morphological classification (Pereira et al., 1995) were further discriminated through isoenzyme analysis.

\begin{tabular}{|c|c|}
\hline $\begin{array}{l}\text { Morphological } \\
\text { groups }\end{array}$ & $\begin{array}{l}\text { Cultivars further discriminated } \\
\text { by isoenzymes }{ }^{z}\end{array}$ \\
\hline $\mathrm{I}$ & P: Inxerta, R: Porteliña \\
\hline II & $\begin{array}{l}\text { P: Blanca, Verde; R: Amarela-Lugo, Burgaceira, } \\
\text { Portuguesa }\end{array}$ \\
\hline III & P: Longal \\
\hline IV & P: Famosa, R: Toubesa \\
\hline V & $\begin{array}{l}\text { P: Garrida, Raigona; R: Xabrega-Trives, Praga } \\
\text { d'Afora, Puga Receiro }\end{array}$ \\
\hline VI & $\begin{array}{l}\text { P: Negral (Courelá-Rubiá, Riá, Xabrega-Rubiá, } \\
\text { Vileta), } \\
\text { R: Arial(Monfortina), Cerreda, Bravoleirado, Salnesa, } \\
\text { Sergude, Serodia }\end{array}$ \\
\hline VII & P: Rapada, R: Maceirá \\
\hline VIII & $\begin{array}{l}\text { P: Amarelante (Abarcá, Anchas), Loura (Pallaregas), } \\
\text { Luguesa (Tarabelao), Parede (Paradesa), Presa } \\
\text { (Veiguiña), } \\
\text { Temporá (Cabezuda, Cedo), Ventura, } \\
\text { R: Calva, Campilla, Carrelao, Horrón, Pelada, } \\
\text { Pozoredondo, Puga, } \\
\text { Redondo, Ribeirá, Rozada, San Miguel, Soutogrande, } \\
\text { Xilimendra. }\end{array}$ \\
\hline
\end{tabular}

${ }^{\mathrm{z}} \mathrm{P}=$ cultivars widely distributed $; \mathrm{R}=$ cultivars grown in small areas

Table 7. Significant Pearson correlation coefficients between the allele frequency and the altitude and climate parameters, immediately below the probability.

\begin{tabular}{|c|c|c|c|c|}
\hline Allele & $\mathrm{ALT}^{\mathrm{z}}$ & $\mathrm{ETI}^{\mathrm{y}}$ & $\mathrm{RAO}^{\mathrm{x}}$ & $\mathrm{RJO}^{\mathrm{w}}$ \\
\hline$\overline{M d h-2 a}$ & 0.204 & -0.240 & 0.339 & 0.258 \\
\hline$M d h-2 b$ & -0.204 & 0.240 & -0.339 & -0.258 \\
\hline$M d h-3 a$ & NS & NS & -0.167 & -0.138 \\
\hline$M d h-3 b$ & NS & NS & 0.167 & 0.138 \\
\hline$I d h-2 a$ & -0.174 & NS & NS & NS \\
\hline$I d h-2 b$ & 0.174 & NS & NS & NS \\
\hline Skdh-a & -0.129 & NS & -0.232 & -0.168 \\
\hline$S k d h-b$ & -0.125 & NS & NS & NS \\
\hline$S k d h-c$ & 0.250 & -0.164 & 0.224 & 0.141 \\
\hline$P g i-2 a$ & NS & NS & NS & 0.147 \\
\hline$P g i-2 b$ & -0.137 & NS & NS & NS \\
\hline$P g i-2 c$ & NS & NS & -0.121 & -0.153 \\
\hline Pgm-2a & NS & -0.018 & NS & NS \\
\hline Pgm-2b & NS & NS & NS & NS \\
\hline
\end{tabular}

${ }^{\mathrm{z} A L T}=$ altitude.

${ }^{\mathrm{y} E T I}=$ effective thermal index of Winkler and Amerine.

${ }^{x} \mathrm{RAO}=$ accumulated rainfall from April to October.

"Idem from July to October.

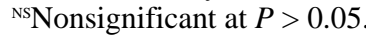

cultivars (data not shown) suggests that the studied alleles are not linked to the morphological traits and explains why the isoenzymic and morphological classifications do not correspond.

\section{Conclusions}

There is important variability within and among cultivars when using the isoenzyme analysis, which confirms the results obtained with morphological traits. Intracultivar variability may lead to important varietal confusions, and therefore clonal selection within cultivars seems to be the most advisable strategy for chestnut improvement.

The high diversity found in this study justifies introducing the material studied to the chestnut germplasm bank which is being installed at the Centro de Investigaciones Forestales de Lourizán.

The isoenzymic classification does not correspond to the morphological one owing to the lack of correlation among most morphological traits and the frequency of the alleles studied (Pereira, 1994). However it allows problems of synonymy to be solved in some cases (Table 6) increasing the information obtained with the morphological study in a classification system of cultivars and synonymies.

These results also recommend the use of isoenzyme techniques for registration and protection of cultivars as a complement of the official method exclusively based on morphological traits.

The correlations between allelic composition and climate and altitude of selection seem to indicate that there was an ecological selection of genotypes better adapted to different situations of rainfall and altitude. This is an observation that we must take into account when recommending cultivars for use in different production areas.

\section{Literature Cited}

Aletà, N., Olarte, C., Truco, M.J., and P. Arús. 1990. Identification of walnut cultivars by isozyme analysis. Acta Hort. 284:91-96.

Bailey, D.C. 1983. Isozymic variation and plant breeders' rights, p. 425440. In: S.D. Tanksley and T.J. Orton (eds.). Isozymes in plant genetics and breeding. Part A. Elsevier Science Publishers, Amsterdam.

Bonnefoi, C. 1984. Etude du polymorphism enzymatique des populations forestières de chataignier, Castanea sativa Miller. PhD diss., Université des Sciences et Techniques du Languedoc, Académie de Montpellier.

Fernández, J. 1992. Variability in Castanea sativa, Castanea crenata and interspecific hybrids for GOT, ACO, APS, PGM, PGI, IDH, MDH, SDH isozymes. In: Abstracts International Symposium on population genetics and gene conservation of forest trees. INRA/IUFOR, Carcans Maubuisson 24-28 Aug.

Fernández, J. and S. Pereira. 1993. Inventario y distribución de los cultivares tradicionales de Castaño (Castanea sativa Mill.) en Galicia. Instituto Nacional de Investigación y Tecnología Agraria y Alimentaria, Ministerio de Agricultura, Pesca y Alimentación.

Fernández, J., S. Pereira, and E. Miranda. 1993. Selección, identificación y esquema de producción de clones híbridos de Castanea sativa Mill. y C. crenata Sieb. et Zucc. o C. mollissima Blume para producción de madera o fruto. Congreso Forestal Español, Lourizán, Spain.

Fernández, J., M. Miranda, and S. Pereira. 1994. Isozymes in the management of a Foundation Stock of chestnut hybrid clones. In: Proceedings of the IUFRO Working Party S2.04-07, Valsain 18-22 Aug. 1992.

Fineschi, S., M.E. Malvolti, M. Morgante, and G.G. Vendramin. 1994. Allozyme variation within and among cultivated varieties of sweet chestnut (Castanea sativa). Can. J. For. Res. 24:1160-1165.

Giannini, R., P. Rossi, and G.G. Vendramin. 1993. Allozyme variation within and among "Marrone Fiorentino" cultivated varieties. Abstract, International Chestnut Congress, Spoleto, Italia.

Goodman, M.M. 1973. Genetic distances: measuring dissimilarity among populations. Yearbook Physical Anthropol. 17:1-38.

Gottlieb, L.D. 1981. Electrophoretic evidence and plant populations. Prog. Phytochem. 7:1-46.

Hidalgo, L. 1980. Caracterización macrofísica del ecosistema medioplanta en los viñedos españoles. MAPA, Serie Producción Vegetal 27 30.

Huang, H., F. Dane, and J.D. Norton. 1994. Genetic analysis of 11 polymorphic isozyme loci in chestnut species and characterization of chestnut cultivars by multi-locus allozyme genotypes. J. Amer. Soc. Hort. Sci. 119:840-849.

Kephart, S.R. 1990. Starch gel electrophoresis of plant isozymes: A comparative analysis of techniques. Amer. J. Bot. 77:69-712. 
Llauradó, M., J. Moreno-González, and P. Arús. 1993. Classification of northern Spanish populations of maize by methods of numerical taxonomy. II. Isozyme variation. Maydica 38:249-258.

Muller-Starck, G., M. Conedera, and S. Fineschi. 1993. Genetic characterization of cultivated varieties of european chestnut (Castanea sativa Mill.) in Southern Switzerland. Abstr. Intl. Congr. Chestnut, Spoleto, Italia.

Nei, M. 1972. Genetic distance between populations. Amer. Naturalist 106:282-293.

Nei, M. 1977. F-statistics and analysis of gene diversity in subdivided populations. Ann. Hum. Genet. 41:225-233.

Pereira, S. 1994. Caracterización y selección de cultivares tradicionales de Castanea sativa Mill. en Galicia. PhD thesis, Universidad Politécnica de Madrid.

Pereira, S., J. Fernández, and J. Moreno-González. 1995. Variability and grouping of Northwestern Spanish chestnut cultivars. I. Morphological traits. J. Amer. Soc. Hort. Sci. (In press.)

Pigliucci, S., Benedetteli, S., and F. Villani. 1990. Spatial patterns of genetic variability in Italian chestnut (Castanea sativa). Can. J. Bot. 68:1962-1967.
Sawano, M., T. Ichii, T. Nakanish, and Z. Kotera. 1984. Study on identification of chestnut species and varieties by isozyme analysis. Sci. Rpt. Fac. Agr. Kobe Univ. 16:67-71.

Shields, C.R., T.J. Orton, and C.W. Stuber. 1983. An outline of general resource needs and procedures for the electrophoretic separation of active enzymes from plant tissues, p. 443-468. In: S.D. Tanksley and T.J. Orton (eds.). Isozymes in plant genetics and breeding, Part A. Elsevier, Amsterdam.

Soller, M. and J.S. Beckmann. 1983. Genetic polymorphism in varietal identification and genetic improvement. Theor. Appl. Genet. 67:25-33.

Vallejos, C.E. 1983. Enzyme activity staining, p. 469-516. In: S.D. Tanksley and T.J. Orton (eds.). Isozymes in plant genetics and breeding, Part A. Elsevier, Amsterdam.

Villani, F., M. Pigliucci, S. Benedettelli, and M. Cherubini. 1991. Genetic differentiation among Turkish chestnut (Castanea sativa Mill.) populations. Heredity 66:131-136.

Wright, S. 1978. Evolution and the genetics of populations. vol. 4. Variability within and among natural populations. Univ. of Chicago Press. 